\title{
PERSUASI PENGURANGAN PENGGUNAAN KANTONG PLASTIK MELALUI NARASI DAN PERSEPSI RESIKO
}

\author{
Gumgum Gumelar \\ Universitas Negeri Jakarta \\ Jl. Rawamangun Muka, Rawamangun, Jakarta Timur, 13220. \\ Telp. (021) 4898486, Email : ggumelar@unj.ac.id
}

\begin{abstract}
Studies on the effect of persuasion message in a pro-environmental behavior context have been focused on the utilization of argumentative massage type to ensure changes in individual's behavior. The purpose of this research is to testing whether persuasion narration on type message, based on the risk in mediation by drifting, can reduce the use of plastic bag. This research method used an experimental method by giving manipulation in reading the material form and fill three instruments for 167 respondents. The result suggests that health-risk framing messages were more likely increase pro-environmental behaviors in use reduction of plastic bags compares to environmental-risk framing messages. This effect appears due to the historical transportation process. This research contributes to literacy of the community of reducing the use of a plastic bag to improve environmentally friendly behavior.
\end{abstract}

Keywords: Plastic bags, Pro-environmental, persuasion, risk.

\begin{abstract}
Abstrak
Penelitian mengenai efek pesan persuasi pada perilaku ramah lingkungan memfokuskan kepada penggunaan tipe pesan argumentasi dalam mengubah perilaku seseorang. Tujuan penelitian ini adalah untuk menguji apakah persuasi narasi dalam tipe pesan, berdasarkan resiko yang di mediasi oleh keterhanyutan, mampu mengurangi penggunaan kantong plastik. Metode penelitian ini menggunakan pendekatan eksperimen dengan pemberian manipulasi berupa bahan bacaan dan mengisi 3 skala pada 167 responden. Hasil penelitian ini menunjukkan bahwa risiko kesehatan lebih mampu meningkatkan perilaku ramah lingkungan berupa pengurangan penggunaan kantong plastik dibandingkan tipe pesan dengan risiko lingkungan. Efek ini terjadi karena melalui proses keterhanyutan. Penelitian ini memberikan kontribusi berupa literasi masyarakat mengenai pengurangan penggunaan kantong plastik yang dapat meningkatkan perilaku ramah lingkungan.
\end{abstract}

Kata Kunci: kantong plastik, ramah lingkungan, persuasi, risiko.

\section{Pendahuluan}

Perubahan iklim, polusi udara, limbah dan isu-isu lingkungan lainnya memiliki dampak pada pemanasan global. Pemanasan global mengakibatkan terjadinya bencana alam yang tidak hanya merusak lingkungan, tetapi juga dapat memiliki pengaruh negatif pada seluruh orang di dunia ini. Seperti yang dijelaskan oleh Doherty dan Clayton (2011: 265) bahwa perubahan iklim global diperkirakan memiliki efek negatif pada kesejahteraan dan kesehatan mental individu.
Bencana alam dapat menyebabkan posttraumatic stress disorder, masalah tidur, depresi, penyalahgunaan obat dan alkohol, tingkat bunuh diri yang tinggi (Fritze, Blahki, Burke, \&Wiseman, 2008:3). Masalah bencana alam ini juga terjadi di Indonesia. Kebakaran hutan di Sumatera dan Kalimantan, banjir dan tanah longsor di beberapa kota di Indonesia, membuat sebagian masyarakat kehilangan atau mengungsi dari rumah tinggalnya sehingga mengakibatkan masalah psikologis yang timbul pada mereka yang terdampak 
bencana. Perubahan iklim global yang terus memburuk, bencana alam berpeluang untuk terus meningkat.

Bencana alam yang akan terjadi dengan perubahan iklim menjadi kepedulian di kalangan peneliti di bidang komunikasi. Usaha untuk mempromosikan perilaku ramah lingkungan (pro-environmental behavior) dalam mengurangi dampak global dari rusaknya lingkungan hidup terus berkembang. Secara tradisional, aktivis ramah lingkungan selama ini mengandalkan bukti statistik yang didukung oleh argumentasi yang rasional dan fakta untuk mempromosikan perilaku ramah lingkungan. Namun, selama sepuluh tahun terakhir sejumlah studi telah menemukan bahwa bentuk-bentuk narasi komunikasi, seperti cerita dan testimonial lebih persuasif dan efektif mengkomunikasikan informasi dan pesan persuasi (Green \& Brock, 2000: 702; Kreuter dkk, 2007: 224).

Belum berhasilnya usaha pelestarian alam dalam penggunaan produk ramah lingkungan dikarenakan sikap skeptis yang muncul. Salah satu contoh sikap skeptis terhadap persuasi ramah lingkungan adalah penggunaan kantong plastik. Kita masih menggunakan kantong plastik karena kita tidak percaya atau mungkin tidak peduli bahwa kantong plastik perlu waktu yang begitu lama untuk terdekomposisi. Walaupun dalam beberapa pesan persuasi telah menunjukkan penelitian tentang kantong plastik dapat mengakibatkan kerusakan alam karena proses terurainya membutuhkan waktu 20 sampai dengan 1.000 tahun untuk bisa benar-benar terdekomposisi, akan tetapi hal tersebut tidak mengurangi penggunaan kantong plastik. Padahal Yayasan Lembaga Konsumen Indonesia http:// ylki.or.id/2011/11/belanja-tanpa-kantongplastik/ dan Gerakan Indonesia Diet Kantong Plastik (http://dietkantongplastik. info/2016/10/13/kebijakan-kantong-plastikberbayar-kontraproduktif/) telah melakukan kampanye akan hal tersebut.

Menurut peneliti, hal ini disebabkan usaha persuasi (kampanye) yang digunakan cenderung menggunakan informasi, data, statistik (argument-driven messages) sebagai bentuk persuasinya. Walaupun penelitian persuasi dengan pesan argumen telah menunjukkan bahwa bukti statistik lebih persuasif dibandingkan dengan persuasi narasi (Ah Yun \& Massi, 2000: 307; Hoeken, 2001: 427; Hoeken \& Hustinx, 2009: 491; Hornikx, 2007: 152; Slater \& Rouner, 2002: 174), karena data statistik lebih kuat memberikan alasan yang logis dan rasional untuk dapat dipercaya. Selain itu informasi atau data argumen dapat membuat persepsi kredibilitas pesan dan sumber yang akan menghasilkan penerimaan pesan yang lebih persuasif. Akan tetapi seperti yang dijelaskan sebelumnya bahwa perilaku ramah lingkungan belum juga memberikan peningkatan yang berarti. Selain macam pesan (argumentatif vs naratif), efek persuasi juga dipengaruhi oleh cara pembingkaian informasi. Rothman dkk (1993: 409) menjelaskan pembingkaian pesan sebagai proses penyajian pesan untuk dapat mempengaruhi individu.

Upaya untuk meningkatkan efektifitas narasi sebagai media persuasi, Green dan Brock (2000: 701) mencoba untuk meneliti 
dampak persuasif narasi untuk melihat sejauh mana penerima yang "hanyut' ke dunia narasi dan menjadi bagian dari protagonis lebih mudah terpersuasi.

Keberhasilan narasi sebagai pesan yang persuasif ditentukan oleh seberapa dalam individu masuk kedalam "cerita" tersebut. Proses tersebut disebut dengan transportation (Green, 2013: 478). Proses ini dalam beberapa literatur ilmiah secara konseptual memiliki definisi yang hampir sama dengan beberapa istilah seperti: Identification (Cohen, 2001: 261), presence (Biocca, 2002: 102), narrative engagement ((Busselle \& Bilandzic, 2009: 322) Absorption (Slater \& Rouner, 2002: 178).

Penelitian yang ada selama ini telah menguji berbagai aspek keterhanyutan dalam narasi untuk menjelaskan bahwa proses ini dapat memiliki dampak yang signifikan dalam merubah sikap dan keyakinan pembaca. Penelitian Green dan Brock merangsang para peneliti untuk menganalisis berbagai aspek keterhanyutan dalam narasi. Penelitian baru dirancang untuk menjelaskan lebih jauh mengenai proses keterhanyutan dalam narasi yang dapat mempengaruhi pengetahuan dan perilaku, sikap (Green \& Brock, 2000: 702), dan keyakinan (Escalas, 2004: 46). Karena keterhanyutan dalam narasi memberikan dampak pada pengetahuan, perilaku, sikap dan keyakinan, maka meneliti cara untuk meningkatkan keterhanyutan seseorang dalam narasi akan menjadi cara yang efektif dalam memodifikasi sikap, keyakinan, intensi dan perilaku dari individu. Hasil peningkatan keterhanyutan dalam narasi memiliki makna khusus bagi para pemerhati ramah lingkungan yang ingin mengkampanyekan perilaku ramah lingkungan yang selama ini belum terlalu sukses meyakinkan pentingnya perilaku ramah lingkungan.

Penelitian mengenai keterhanyutan dalam narasi menunjukkan keberhasilan dalam mempersuasi individu, akan tetapi beberapa penelitian juga telah menemukan bahwa keterhanyutan tidak konstan tetapi bisa sangat bervariasi tergantung pada individu dan narasi. Individu sering tidak mengalami keterhanyutan pada saat yang sama atau pada tingkat yang sama (Wang \& Calder, 2006: 155). Demikan pula yang dijelaskan oleh Green dan Brook (2004: 719) bahwa tinggi dan rendahnya tingkat keterhanyutan dapat bergantung pada faktor-faktor seperti atribut dari pesan (misalnya, kualitas cerita, instruksi, kejelasan) dan atribut individu (misalnya, transportability dari individu).

Narasi persuasi dapat digunakan untuk mengatasi resistensi. Resistensi didefinisikan sebagai "people's motivated effort to defend an attitude against change" (Cin, Zanna, \& Fong, 2004: 177). Keterhanyutan dalam narasi dapat mengatasi resistensi dengan mengurangi perhatian terhadap kontradiksi apapun serta mengurangi efek dari paparan narasi terduga (Cin, Zanna, \& Fong, 2004: 178). Individu, ketika benar-benar "hanyut" dalam sebuah cerita, cenderung untuk menurunkan pertahanan keyakinan pribadinya. Menyukai karakter tertentu yang pada akhirnya memiliki efek pada keterhanyutan dalam narasi serta pada efek persuasif dari narasi.

Saat individu memproses narasi, individu menjadi terbenam, hanyut ke dalam dunia narasi, dan terpisah dari dunia mereka sendiri 
(Gerrig, 1993: 3; Green \& Brock, 2000: 702, 2005: 118). Green dan Brock (2000: 702) menjelaskan keterhanyutan dalam narasi terjadi saat semua sistem mental dan kapasitasnya menjadi fokus pada peristiwa yang terjadi dalam narasi. Sejak mereka meninggalkan dunia mereka sendiri saat membaca narasi.

Pemrosesan narasi dapat dianggap jenis pemrosesan yang berbeda dengan pemrosesan analitik. Pada penelitian konsumen, keterhanyutan dalam narasi telah secara empiris diuji dan didukung sebagai mendasari mekanisme di mana narasi mampu mengarah pada persuasi (Chang, 2009: 22; Escalas, 2004: 38).

Teori keterhanyutan dalam narasi menjelaskan bahwa pemrosesan narasi mempengaruhi keyakinan, sikap, dan evaluasi dunia dari narasi dan protagonis (Green \& Brock, 2000: 702, 2005: 118). Dalam penelitian perilaku konsumen, menunjukkan bahwa narasi iklan, dibandingkan dengan iklan argumentatif, memunculkan lebih banyak recall dari isi iklan (Smith dkk, 1995: 736); reaksi afektif (Deighton dkk, 1989: 335; Escalas, 2004: 38); berkurangnya counterargument (Deighton dkk, 1989: 335; Escalas, 2004: 38); keterlibatan narasi (Polyorat, Alden \& Kim, 2007: 539); dan sikap/evaluasi yang menguntungkan terhadap merek (Escalas, 2004: 38).

Hal lain yang mempengaruhi efekpersuasi yang telah disebutkan sebelumnya, faktor persepsi terhadap resiko menjadi penting pada penelitian mengenai perilaku ramah lingkungan. Faktor ini penting dikarenakan persuasi (sikap dan/atau perubahan niat) tidak dapat terjadi jika seseorang tidak merasakan risiko. Persepsi risiko mengacu pada penilaian subjektif orang tentang kemungkinan suatu peristiwa yang merugikan dan kepedulian mereka tentang konsekuensi (Sjoberg, 2004: 52; Slovic, 1987: 280).

Usaha untuk meningkatkan kelestarian alam salah satunya dengan mengurangi penggunaan plastik, yang perlu terus dipromosikan. Perlu usaha untuk mengurangi penggunaan kantong plastik yang salah satunya dengan membuat pesan/kampanye yang baik. Salah satu upaya tersebut dengan mencoba memasukkan atribut psikologis yaitu persepsi risiko ke dalam bentuk kampanye naratif yang sudah dijelaskan sebelumnya.

Persepsi risiko didasarkan pada sejumlah faktor psikologis, sosial, budaya, dan kontekstual, serta atribusi terhadap risiko sendiri (Sjoberg, 2004: 52; Slovic, 1987: 283). Penilaian ini melibatkan "keyakinan, sikap, penilaian dan perasaan, serta disposisi budaya dan sosial seseorang yang mereka fahami mengenai bahaya dan manfaat untuk diri mereka (Pidgeon dkk, 1992: 89). Oleh karena itu persepsi risiko dengan probabilitas tujuan yang sama (yaitu, risiko probabilistik penilaian) dapat dirasakan berbeda oleh orang yang sama (Slovic, 1987: 283).

Penelitian mengenai persepsi terhadap risiko menjadi penting dalam persuasi. Akan tetapi perlu dipertimbangkan tentang perbedaan dari jenis risiko yang terkait dengan tema dari penelitian ini yaitu risiko kesehatan dan risiko lingkungan.

Risiko kesehatan manusia adalah risiko yang mudah dilihat secara langsung dan terutama mempengaruhi manusia, tanpa efek samping yang jelas pada unsur-unsur nonmanusia dari ekosistem. Risiko yang termasuk 
dalam kategori ini termasuk kanker, serangan jantung, dan HIV / AIDS (Kahlor dkk, 2006: 163). Sedangkan risiko lingkungan adalah ancaman terhadap manusia dan hal yang dihasilkan oleh manusia karena perubahan lingkungan, baik sistemik atau kumulatif, ditularkan melalui lingkungan alam dengan konsekuensi negatif bagi manusia dan bukan manusia dari ekosistem seperti tanaman, hewan, dan habitat mereka. Sifat berbeda dari persepsi risiko untuk pesan framing baik sebagai risiko bagi kesehatan atau risiko terhadap lingkungan, dan sebagai kerangka kerja untuk mempelajari bentuk pesan yang dirasakan berbeda untuk kedua jenis risiko ini.

Kahneman dan Tversky (1979: 274) menyebutkan bahwa berbagai cara penyajian pesan dapat memengaruhi luaran risiko dari keputusan yang dibuat oleh sang penerima pesan. Hal ini menyebabkan pembingkaian pesan dapat menjadi salah satu cara untuk meningkatkan daya persuasi suatu pesan.

Keefektifan pembingkaian pesan dalam hal pengubahan sikap dan pengambilan keputusan penerima pesan ini telah banyak diuji, namun sejauh ini belum diperoleh hasil yang dengan pasti menyimpulkan teori tentang pembingkaian pesan yang efektif dan berpengaruh dalam proses pengambilan keputusan si penerima pesan (Cox \& Cox, 2001: 92). Beberapa studi bahkan menyatakan tidak adanya pengaruh pembingkaian pesan (Van Assema, Martens, Ruiter, \& Brug, 2001: 436).

Tujuan penelitian ini adalah untuk menguji apakah persuasi narasi dalam tipe pesan, berdasarkan resiko yang di mediasi oleh keterhanyutan, mampu mengurangi penggunaan kantong plastik.

\section{Metode Penelitian}

Partisipan dari penelitian ini berjumlah 180 partisipan yang berasal dari mahasiswa prodi psikologi UNJ. Penelitian ini menggunakan material cetak berupa manipulasi cerita dan kuesioneryang sudah disiapkandidalam sebuah booklet. Selanjutnya peneliti mempersilahkan partisipan untuk masuk ke dalam ruangan yang telah disiapkan diawali dengan mengisi Behavioral Activating System/Behavioral Inhibition System untuk mengontrol emosi dan keadaan motivasi dari individu sehingga berada dalam keadaan yang sama ketika akan memulai membaca pesan yang diberikan. Pesan yang diberikan menggunakan pesan yang sama dengan tahap uji coba penelitian. Pesan yang diberikan terdiri dari 4 jenis pesan. Usaha dalam mengontrol manipulasi yang diberikan pada partisipan menggunakan proses random assignment. Partisipan akan mendapatkan pesan pengurangan penggunaan kantong plastik sesuai hasil randomisasi yang dilakukan. Setelah selesai, peserta kemudian diminta untuk mengisi kuesioner yang sudah disiapkan. Kuesioner terdiri dari skala keterhanyutan, skala efek persuasi dan uji perlakuan.

Setelah partisipan selesai mengerjakan seluruh form dan prosedur, peneliti melakukan debrief untuk tidak menceritakan proses penelitian ini ke pihak lain. Peneliti juga memberikan informasi tentang kerahasiaan dalam penelitian. Peneliti menutup debriefing dengan mengucapkan terimakasih dan memberikan tanda terimakasih untuk partisipan. 
Efek persuasi untuk studi ini diukur dalam bentuk self report dari partisipan. Pengukuran dengan menggunakan tujuh butir pernyataan untuk mengukur keputusan. Keputusan mengurangi kantong plastik diukur dalam bentuk self report partisipan dengan menggunakan tujuh butir pernyataan. Variabel mediator penelitian eksperimen ini adalah keterhanyutan saat membaca pesan (narrative transportation) yang diukur untuk melihat sejauh mana isi pesan yang diberikan memberikan efek keterhanyutan yang dapat meningkatkan efek persuasi. Pengukuran ini menggunakan SF-Form Transportion narrative dari Green (2000: 701-721) yang dikembangkan oleh Appel (2010: 32).

Uji validitas dan realibilitas skala efek persuasi dari keputusan untuk mengurangi kantong plastik dilakukan untuk menyeleksi butir pernyataan yang akan digunakan untuk mendapatkan keputusan dari partisipan. Teknik principal axis factoring (PAF) digunakan dengan ekstraksi 1 faktor. Tidak perlu lagi dilakukan teknik rotasi. Sebesar $32.510 \%$ varians di dalam skala dapat dijelaskan oleh satu faktor. Bila ukuran sampel 120, menurut Pituch dan Steven (2016) nilai factor loading yang signifikan berada diatas 0,3 . Sehingga dari semua butir pernyataan skala efek persuasi berupa putusan, 5 butir pernyataan digunakan dan 2 butir pernyataan digugurkan untuk mengukur perilaku ramah lingkungan dari partisipan.

Analisis reliabilitas dengan menggunakan Cronbach's alpha adalah 0,582. Nilai yang didapat dari pengukuran reliabilitas sebesar 0,582 menunjukkan bahwa skala keputusan dianggap reliabel atau cukup baik (Kaplan \& Saccuzzo, 2012)
Keterhanyutan merupakan kecenderungan individu untuk mengalami absorbsi di dalam bacaan sebagai respons terhadap bacaan dari narasi. Skala ini disusun dengan menggunakan skala likert dengan 11 pilihan, yaitu 0 sangat tidak setuju (STS), sampai dengan 10 sangat setuju (SS). Jumlah butir pernyataan pada skala ini awalnya sebanyak 8 butir pernyataan.

Uji validitas dan realibilitas skala keterhanyutan menggunakan validasi dan reliabilitas yang sudah diukur sebelumnya di studi pertama, 8 butir pernyataan digunakan dan satu butir pernyataan digugurkan untuk mengukur keterhanyutan dari partisipan. Analisis reliabilitas dengan menggunakan Cronbach's alpha adalah 0,751. Nilai yang didapat dari pengukuran reliabilitas sebesar 0,751 menunjukkan bahwa skala keterhanyutan dianggap reliabel atau cukup baik (Kaplan \& Saccuzzo, 2012).

\section{Uji Perlakuan (manipulation check)}

Uji perlakuan menggunakan 4 butir pernyataan dalam bentuk semantik seperti studi pertama, yaitu untuk menilai "apakah pesan tersebut menekankan pada" (1) diri pribadi lingkungan, (2) dampak kesehatan - dampak lingkungan (3) fakta/informasi - tokoh/ karakter (3) penelitian - tindakan dari tokoh/ karakter, dalam usaha untuk mengurangi penggunaan kantong plastik.

Untuk manipulasi cek pada risiko menggunakan butir pernyataan yang sama yaitu apakah pengurangan penggunaan kantong plastik itu (i) buruk - baik, (ii) tidak bermanfaat bermanfaat (iii) negatif - positif, (iv) tidak bertanggung jawab - bertanggung jawab, (v) berbahaya - aman, dan (vi) bebal - bijaksana. 
Tujuan dari penelitian akan diuji dengan menggunakan ANOVA F-test untuk mengetahui perbedaan rerata antar variasi dari isi pesan persuasi yang dibuat. Selanjutnya dilakukan pengujian uji mediasi dengan Hayes model-4 untuk mengukur efek mediasi keterhanyutan pada pengaruh variabel bebas pada variabel tergantung.

\section{Hasil Penelitian dan Pembahasan}

Dari hasil penelitian ini didapatkan hasil Main effect pesan narasi terhadap keputusan untuk tidak menggunakan kantong plastik berbeda secara signifikan, $F(1,167)=$ 30.657, $p<0.05, \eta^{2}=0,155$, dengan rerata keputusan pada pesan narasi lebih tinggi $\left(M_{\text {narasi }}=7.5138 ; \mathrm{SD}=0,74135\right)$ daripada pesan argumentasi $\left(M_{\text {argumentasi }}=6,976\right.$; $\mathrm{SD}=0,61969)$. Kelompok partisipan yang mendapatkan pesan persuasi dalam bentuk pesan narasi memiliki keputusan yang lebih tinggi untuk tidak menggunakan kantong plastik daripada kelompok partisipan yang mendapatkan isi pesan persuasi dalam pesan argumentasi.

Hasil analisis data untuk mengetahui efek mediasi menggunakan uji Sobel. Uji Sobel merupakan alat analisis untuk menguji signifikansi dari hubungan tidak langsung antara variabel bebas dengan variabel terikat yang dimediasi oleh variabel mediator. Dari hasil pengujian didapatkan hasil melalui uji Sobel yaitu, $\mathrm{z}=2.6581>1,96$ dengan tingkat signifikansi $0,000<0,01$. Hasil tersebut menjelaskan bahwa ada peran yang signifikan pada keterhanyutan untuk memediasi pengaruh pesan narasi terhadap tingkah laku ramah lingkungan dalam keputusan tidak menggunakan kantong plastik.
Dari perhitungan statistik yang dilakukan untuk melihat variabel bingkai pesan risiko secara signifikan berbeda terhadap keputusan untuk tidak menggunakan kantong plastik, $\mathrm{F}(1,167)=20.488, P<0.05, \eta^{2}=0,109$. Keputusan pada pesan persuasi dengan bingkai pesan risiko individu lebih tinggi $\left(M_{\text {individu }}=\right.$ 7.4643; $\mathrm{SD}=0,73140)$ daripada bingkai pesan risiko lingkungan ( $M_{\text {lingkungan }}=7,0301$; $\mathrm{SD}=0,67165)$. Kelompok partisipan yang mendapatkan pesan persuasi dengan bingkai pesan risiko individu memiliki keputusan untuk tidak menggunakan kantong plastik yang lebih tinggi daripada kelompok partisipan yang mendapatkan bingkai pesan risiko lingkungan. Ini membuktikan bahwa bingkai pesan risiko individu memiliki kemampuan meningkatkan tingkah laku ramah lingkungan dalam keputusan untuk tidak menggunakan kantong plastik.

Hasil ANOVA yang dilakukan menunjukkan hasil lanjutan yaitu mengenai efek interaksi. Hasilnya menunjukkan bahwa terdapat interaksi yang signifikan antara pesan persuasi dan bingkai pesan risiko dengan nilai $\mathrm{F}(1,167)=5.514, P<0.05 ; \eta^{2}=0,032$. Ketika kelompok partisipan mendapatkan pesan persuasi dan bentuk pesan narasi, pesan narasi dengan bingkai pesan risiko individu memiliki keputusan untuk tidak menggunakan kantong plastik lebih tinggi $\left(M_{\text {narasi individu }}=7.8506 ; \mathrm{SD}=\right.$ 0,56555) daripada kelompok pesan narasi bingkai pesan risiko lingkungan $\left(M_{\text {narasi }}\right.$ lingkungan $=7,1769 ; \mathrm{SD}=0,74828)$. Demikian pula ketika kelompok partisipan mendapatkan pesan persuasi argumentasi, pesan persuasi argumentasi dengan bingkai pesan risiko individu memiliki keputusan untuk tidak 
menggunakan kantong plastik ( $M_{\text {argumentasi_ }}$ individu $=7,0779 ; \mathrm{SD}=0,74828$ ) lebih tinggi daripada kelompok isi pesan argumentasi dengan bingkai pesan lingkungan ( $M_{\text {argumentasi }}$ lingkungan $=6,8645 ; S D=0,61969)$. Hasil ini menunjukkan bahwa ketika mendapatkan isi pesan persuasi narasi, pesan persuasi dengan bingkai pesan risiko individu berpengaruh pada keputusan untuk tidak menggunakan kantong plastik dibandingkan dengan pesan persuasi dengan bingkai pesan risiko lingkungan.

Main effect pesan persuasi terhadap keterhanyutan berbeda secara signifikan, $\mathrm{F}(1,167)=9,702 ; \eta^{2}=0,055$, dengan keterhanyutan pada pesan narasi lebih tinggi $\left(M_{\text {narasi }}=7.2614 ; \mathrm{SD}=1,17648\right)$ daripada isi pesan pesan argumentasi $\left(M_{\text {argumentasi }}=6,7401\right.$; $\mathrm{SD}=1,00401)$. Kelompok partisipan yang mendapatkan pesan persuasi dalam bentuk pesan narasi lebih memiliki keterhanyutan yang tinggi daripada kelompok partisipan yang mendapatkan pesan persuasi dalam bentuk pesan argumentasi.

Secara keseluruhan, hasil menunjukkan bahwa untuk pesan bingkai pesan terhadap risiko, pesan narasi dibandingkan dengan pesan argumentasi yang dihasilkan meningkatkan efek persuasi pada partisipan. Hasil ini konsisten dengan penelitian lain yang melibatkan risiko dan persuasi, serta dengan studi yang menggabungkan berbagai jenis bukti (mis Chang, 2009: 22; de Wit, Das \& Vet, 2008 : 113; Polyorat, Alden \& Kim, 2007: 539). Penelitian ini sejalan dengan penelitian de Wit dkk (2008: 113) yang menemukan bahwa pesan dalam bentuk narasi memiliki efek persuasi lebih besar dibandingkan argumentasi ataupun bukti statistik.

Teori keterhanyutan konsisten dengan hasil penelitian yang telah dilakukan. Hasil penelitian menunjukkan bahwa partisipan menunjukkan counterarguments lebih sedikit ketikamerekaberadadalamketerhanyutanyang lebih besar. Selanjutnya, hasil menunjukkan bahwa keterhanyutan memiliki kedua efek langsung dan tidak langsung pada tingkah laku ramah lingkungan yang berorientasi dampak. Pertama, keterhanyutan memiliki hubungan positif dengan perilaku ramah lingkungan; meningkatnya keterhanyutan menyebabkan

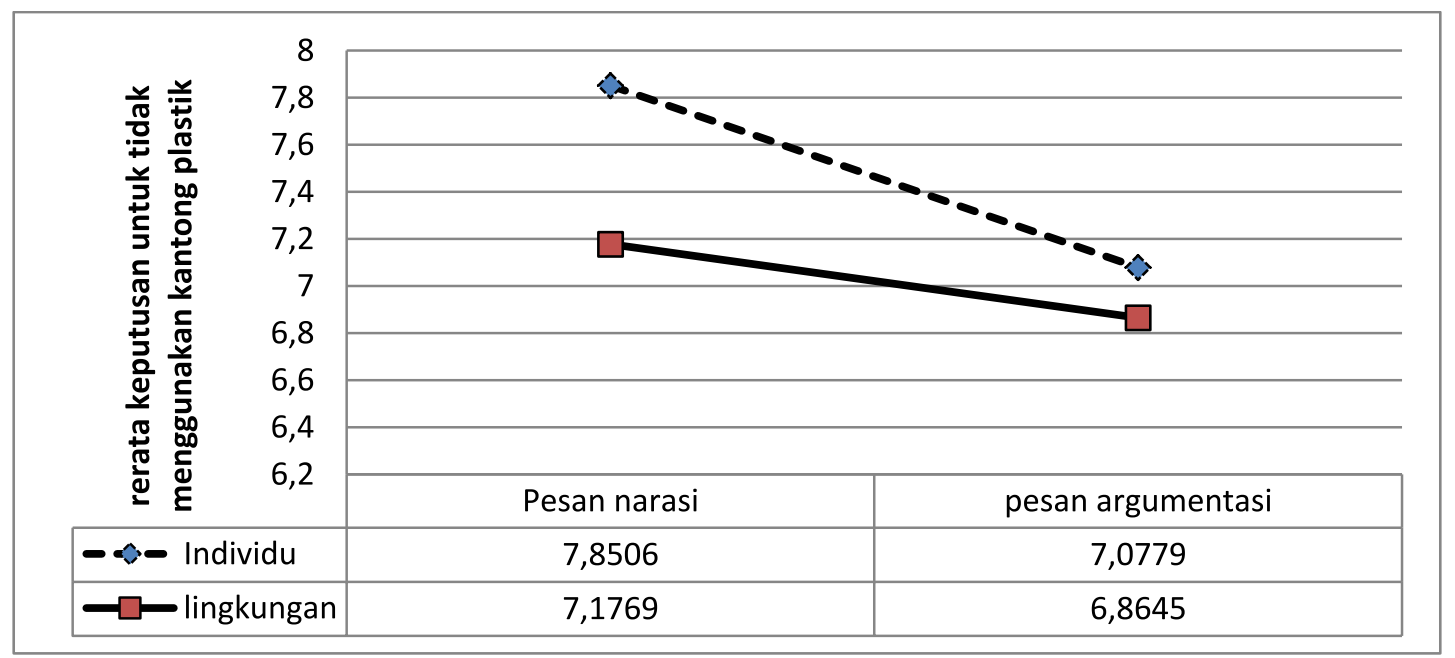

Gambar 1. Grafik interaksi isi pesan persuasi dan bingkai pesan risiko terhadap keputusan untuk tidak menggunakan kantong plastik. (Sumber : Data Peneliti, 2017) 
konsistensi antara pesan dalam pesan narasi dengan perilaku ramah lingkungan. Selain itu, keterhanyutan memediasi hubungan antara pesan dan bingkai pesan risiko dengan perilaku ramah lingkungan untuk keputusan tidak menggunakan kantong plastik.

Selain meneliti peran pesan yang berbeda pada persuasi dan bagaimana keterhanyutan dapat menjelaskan beberapa fenomena ini, dampak dari bingkai pesan juga diteliti. Main effect untuk pesan persuasi yaitu pesan narasi dan pesan argumentasi, akan tetapi main effect untuk bingkai pesan tidak didapatkan. Kurangnya bukti yang kuat untuk mendukung bukti persuasif yang relevan mengenai bingkai pesan terkait dengan dalam penelitian ini memiliki beberapa dukungan dalam literatur seperti penelitian Schneider dkk (2001: 264). Penelitiannya menunjukkan keuntungan persuasif untuk pesan berbingkai risiko mungkin hanya berlaku untuk segmen tertentu dari populasi.

Sejalan dengan penelitian lain bahwa ada sedikit perbedaan dalam pesan persuasif berdasarkan bingkai pesan (O'Keefe \& Jensen, 2007: 624) terhadap keterhanyutan, studi ini juga menemukan bahwa bingkai pesan saja bisa memengaruhiefek pesan persuasi. Namun, bingkai pesan tidak menghasilkan efek interaksi yang signifikan dengan jenis pesan dimana kondisi pesan perssuasi tidak memiliki keterhanyutan. Interaksi ini dapat membantu untuk menjelaskan salah satu kondisi dimana bingkai pesan risiko individu mungkin efektif dalam berkomunikasi mengenai perilaku ramah lingkungan, ketika narasi digunakan sebagai pesan persuasi.
Temuan penelitian ini menunjukkan bahwa pembingkaian pesan dalam konteks ramah lingkungan tidak selamanya memberikan efek perbedaan persuasi seperti temuan penelitian pembingkaian pesan dalam konteks perilaku ramah lingkungan di negara maju (Davis, 1995: 295). Hal ini disebabkan pembingkaian pesan dapat memberikan efek yang berbeda tergantung pada faktor disposisional dan situasional. Faktor situasional meliputi aspek atau karakteristik suatu lingkungan tertentu yang secara spesifik berbeda dengan lingkungan lain. Sementara, faktor disposisional meliputi serangkaian pola sikap atau mood spesifik sebagai respon terhadap kehidupan sekitar.

Temuan penelitian ini juga mengindikasi bahwa teori pembingkaian pesan belum konklusif menjelaskan efek pembingkaian pesan pada sikap, niat dan perilaku. Fenomena ini membuka peluang bagi penelitian mendatang untuk menguji efek pembingkaian pesan pada kelompok partispan yang berbeda baik secara demografis maupun geografis. Penelitian mendatang dapat dilakukan pada kelompok partisipan yang berbeda seperti masyarakat luas bukan hanya kepada mahasiswa.

Mahasiswa sebagai subjek dari penelitian ini cenderung memiliki karakter yang kritis, bebas, praktis dan tidak terlalu terikat oleh aturan-aturan. Isu risiko lingkungan yang disampaikan tidak serta-merta membuat mereka percaya dan meyakini konsekuensinya. Demikian pula dengan anjuran untuk berperilaku ramah lingkungan, mereka cenderung resisten karena merasa hal itu akan mengganggu fleksibiltas kegiatan 
mereka sehari-hari. Temuan yang tidak signifikan dalam penelitian ini mungkin disebabkan karena faktor karakteristik partisipan yang memang cenderung resisten terhadap isu yang menjadi topik penulisan. Selain itu penelitian pembingkaian pesan mendatang dapat dilakukan pada konteks perilaku lain yang lebih berisiko.

\section{Simpulan}

Simpulan secara keseluruhan dari penelitian ini hasil menunjukkan bahwa untuk pesan bingkai pesan terhadap risiko, pesan narasi dibandingkan dengan pesan argumentasi yang dihasilkan meningkatkan efek persuasi pada partisipan dalam perilaku pengurangan penggunaan kantong plastik. Tingginya efek persuasi pada pesan narasi dimediasi oleh keterhanyutan dalam narasi. Semakin individu terhanyut dalam pesan narasi dengan pesan bingkai risiko kesehatan, maka semakin tinggi efek persuasi yang terjadi dalam persuasi pengurangan penggunaan kantong plastik.

Penelitian ini diharapkan dapat memberikan kontribusi untuk penelitian sebelumnya dengan mengungkapkan bahwa setiap isi pesan persuasi dan bingkai pesan narasi dikondisikan untuk masalah kesehatan individu adalah yang paling persuasif. Selain itu, keterhanyutan memediasi hubungan antara interaksi isi pesan dan bingkai pesan. Oleh karena itu, keterhanyutan mungkin dapat menjelaskan beberapa alasan mengapa penggunaan pesan narasi dan bingkai pesan risiko individu lebih efektif untuk jenis masalah lingkungan hidup.

Implikasi dari penelitian ini adalah usaha mengintegrasikan dua teori persuasi yaitu teori jenis pesan dan pembingkaian pesan. Temuan ini memberikan implikasi teoretis bagi pelaksanaan penelitian mendatang. Integrasi jenis pesan persuasi dengan pembingkaian pesan masih perlu dikaji lebih lanjut untuk mengkonfirmasi kemungkinan integrasi kedua teori persuasi ini.

Pada konteks komunikasi perilaku ramah lingkungan, integrasi kedua teori inipun juga relevan untuk diteliti lebih lanjut. Peneliti menduga, bentuk variasi manipulasi yang berbeda, serta peningkatan kekuatan pesan yang disampaikan dalam manipulasi bingkai pesan risiko, dapat memberikan efek yang lebih kuat pada penelitian mendatang. Variasi manipulasi yang peneliti usulkan adalah manipulasi risiko dengan bingkai positif dan negatif untuk masing-masing risiko individu dan risiko lingkungan.

\section{Daftar Pustaka}

Ah Yun, J., \& Massi, L. L. (2000). The differential impact of race on the effectiveness of narrative versus statistical appeals to persuade individuals to sign an organ donor card. Paper presented at the meeting of the Western States Communication Association, Sacramento, CA.

Appel, M., \& Richter, T. (2010). Transportation and need for affect in narrative persuasion: A mediated moderation model. Media Psychology, 13(2), 101-135.

Biocca, F. (2002). The evolution of interactive media. In M. C. Green, J. J. Strange, \& T. C. Brock (Eds.), Narrative impact. Social and cognitive foundations (pp. 97-130). Mahwah, NJ: Lawrence Erlbaum Associates.

Busselle, R., \& Bilandzic, H. (2009). Measuring narrative engagement. Media Psychology, 12(4), 321-347. 
Chang, C. (2009). "Being Hooked” By Editorial Content: The Implications for Processing Narrative Advertising. Journal of Advertising, 38 (1), 21-34.

Cin, S. D, Zanna, M. P. \& Fong, G. T. (2004). Narrative persuasion and overcoming resistance. In E. S. Knowles \& J. A. Linn (Eds.), Resistance and persuasion (pp. 175-191). Mawah, NJ: Erlbaum.

Cohen, J. (2001). Defining identification: A theoretical look at the identification of audiences with media characters. Mass Communication \& Society, 4(3), 245-264.

Cox, D., \& Cox, A. D. (2001). Communicating the consequences of early detection: The role of evidence and framing. Journal of Marketing, 65(3), 91-103.

Davis, J. J. (1995). The effects of message framing on response to environmental communications. Journalism \& Mass Communication Quarterly, 72(2), 285-299.

De Wit, J. B., Das, E., \& Vet, R. (2008). What works best: objective statistics or a personal testimonial? An assessment of the persuasive effects of different types of message evidence on risk perception. Health Psychology, 27(1), 110.

Deighton, J., Romer, D., \& McQueen, J. (1989). Using drama to persuade. Journal of Consumer research, 16(3), 335-343.

Doherety, T.J., \& Clayton, S. (2001). The psychological impacts of global climate change. American Psychologist, 66(4), 265-276

Escalas, J. E. (2004). Imagine yourself in the product: Mental simulation, narrative transportation, and persuasion. Journal of Advertising, 33, 37-48.

Fritze, J.G., Blashki, G.A., Burke, S. \& Wiseman, J. (2008). Hope, despair, and transformation: Climate change and the promotion of mental health and wellbeing. International Journal of Mental Health Systems, 2(13). 1- 10

Gerrig, R. J. (1993). Experiencing narrative worlds: On the psychological activities of reading. Yale University Press.

Green, M. C., \& Brock, T. C. (2000). The role of transportation in the persuasiveness of public narratives. Journal of Personality and Social Psychology, 79, 701-721.

Green, M.C., \&Clark, J.L.(2013). Transportation into narrative worlds: implications for entertainment media influences on tobacco use. Addiction, 108(3), 477-484.

Green, M. C., \& Brock, T. C. (2005). Persuasiveness of narratives. Persuasion: Psychological insights and perspectives, 2, 117-142.

Hoeken, H. (2001). Anecdotal, statistical, and causal evidence: Their perceived and actual persuasiveness. Argumentation, $15,425-437$.

Hoeken, H. \& Hustinx, L. (2009). When is Statistical Evidence Superior to Anecdotal evidence in Supporting Probability Claims? The Role of Argument Type. Human Communication Research, 35(4), 491-510.

Hornikx, J. (2005). A review of experimental research on the relative persuasiveness of anecdotal, statistical, causal, and expert evidence. Studies in Communication Sciences, 5(1), 205-216.

Hornikx, J. (2007). Is anecdotal evidence more persuasive than statistical evidence? A comment on classic cognitive psychological studies. Studies in Communication Sciences, 7(2).

Kahlor, L., Dunwoody, S., Griffin, R. J., \& Neuwirth, K. (2006). Seeking and processing information about impersonal risk. Science Communication, 28(2), 163-194. 
Kahneman, D., \& Tversky, A. (1979). Prospect theory: An analysis of decision under risk. Econometrica: Journal of the econometric society, 263-291.

Kaplan, .M., \& Sacuzzo, D .P. (2012) Psychological Testing: Principles, Applications, and issues $8^{\text {th }}$ Ed. Belmpnt: Thomson Wadsworth

Klein, J. G., \& Ahluwalia, R. (2005). Negativity in the evaluation of political candidates. Journal of Marketing, 69(1), 131-142.

Kreuter, M. W., Green, M. C., Cappella, J. N., Slater, M. D., Wise, M. E., Storey, D., \& Hinyard, L. J. (2007). Narrative communication in cancer prevention and control: a framework to guide research and application. Annals of Behavioral Medicine, 33(3), 221-235.

O'Keefe, D. J. \& Jensen, J. D. (2007). The relative persuasiveness of gain-framed loss-framed messages for encouraging disease prevention behaviors: A metaanalytic review. Journal of Health Communication, 12(7), 623-644.

Polyorat, K., Alden, D. L., \& Kim, E. S. (2007). Impact of narrative versus factual print ad copy on product evaluation: The mediating role of ad message involvement. Psychology \& Marketing, 24(6), 539-554.

Pidgeon, N., Hood, C., Jones, D., Turner, B., \& Gibson, R. (1992). Risk perception. Risk: Analysis, perception and management, 89-134.

Rothman, A. J., Salovey, P., Antone, C., Keough, K., \& Martin, C. D. (1993). The influence of message framing on intentions to perform health behaviors. Journal of experimental social psychology, 29(5), 408-433.

Smith, S. M., Haugtvedt, C. P., Jadrich, J. M., \& Anton, M. R. (1995). Understanding
Responses to Sex Appeals in Advertising: An Individual Difference Approach. Advances in consumer research, 22(1), 735-739.

Slater, M. D., \& Rouner, D. (2002). Entertainment-education and elaboration likelihood: Understanding the processing of narrative persuasion. Communication Theory, 12(2), 173-191.

Sjöberg, L. (2004). Explaining individual risk perception: the case of nuclear waste. Risk Management, 9(1),51-64.

Slovic, P. (1987). Perception of risk. Science, 236(4799), 280-285.

Schneider, T. R., Salovey, P., Apanovitch, A., Pizarro, J., McCarthy, D., Zullo, J. \& Rothman, A. J. (2001). The effects of message framing and ethnic targeting on mammography use among low-income women. Health Psychology, 20(4), 256-266.

Van Assema, P., Martens, M., Ruiter, R. A., \& Brug, J. (2001). Framing of nutrition education messages in persuading consumers of the advantages of a healthy diet. Journal of Human Nutrition and Dietetics, 14(6), 435-442.

Wang, J., \& Calder, B. J. (2006). Media transportation and advertising. Journal of Consumer Research, 33(2), 151-162.

\section{Internet :}

Gerakan Indonesia Diet Kantong Plastik (2016) Kebijakan Kantong Plastik Berbayar Kontraproduktif. Retrieved November 2016, http://dietkantongplastik. info/2016/10/13/kebijakan-kantongplastik-berbayar-kontraproduktifl

Yayasan Lembaga Konsumen Indonesia (2011) Belanja Tanpa Kantong Plastik. Retrieved November 2016, http://ylki.or.id/2011/11/ belanja-tanpa-kantong-plastik/ 